\title{
IMPACT OF SUPPLEMENTARY MORINGA OLEIFERA LEAF EXTRACT ON RUMINAL NUTRIENT DEGRADATION AND MITIGATING METHANE FORMATION IN VITRO
}

\author{
Yosra A. Soltan ${ }^{1 *}$, A. S. Morsy ${ }^{2}$, Nesreen M. Hashem ${ }^{1}$, and S. M.A. Sallam ${ }^{1}$ \\ ${ }^{1}$ Department of Animal and Fish production, Faculty of Agriculture, Alexandria University, Alexandria, \\ Egypt. \\ ${ }^{2}$ Livestock Research Department, Arid Land Cultivation Research Institute, City of Scientific Research \\ and Technological Applications, Alexandria, Egypt.
}

*Corresponding author. Email: uosra_eng@yahoo.com

(Received 6/2/2019, accepted 27/3/2019)

\section{SUMMARY}

$\mathrm{P}$ lant extracts may be highly effective as natural dietary supplementation options to alternate the dietary antibiotics as growth promotors in ruminant diets. The current study was conducted to evaluate the dose response effects of the moringa (Moringa oleifera) leaf extract (MLE) as a natural alternative to monensin in sheep diets, on ruminal methane production $\left(\mathrm{CH}_{4}\right)$, gas production (GP), nutrient degradability and fermentation parameters. The in vitro semi-automatic system of GP was used. The treatments were MLE added to a basal diet (consisted of 50 concentrate: 50 forage) at 0 (control), 50 (MLE low) and 500 $\left(\mathrm{MLE}_{\text {high }}\right) \mathrm{mg} / \mathrm{kg}$ dry matter, and the ionophore antibiotic monensin was added at $40 \mathrm{mg} / \mathrm{kg}$ dry matter. Abundant quantities of essential amino acids, monosaccharides, glycosides and benzene derivatives phytochemicals components were detected by the GC-MS analysis of MLE. The most effective treatments to decrease $(\mathrm{P}<0.05) \mathrm{CH}_{4}$ were monensin and $\mathrm{MLE}_{\text {high }}$, while only MLE ${ }_{\text {high }}$ enhanced $(\mathrm{P}<0.05)$ the overall mean of total volatile fatty acids (VFAs) concentrations compared to the other treatments and the molar proportion of acetate compared to monensin. A decline $(\mathrm{P}<0.05)$ in protozoal count was observed by monensin, while such effect did not appear at other treatments. No significant differences were observed among the experimental treatments in the ruminal degradability, ammonia concentrations or GP. This study demonstrated efficiency of MLE as an effective natural intervention to monensin in sheep diets.

Keywords: Methanogenesis, monensin, ruminal fermentation and moringa leaf.

\section{INTRODUCTION}

Methane $\left(\mathrm{CH}_{4}\right)$ emission from ruminants represents a considerable loss of dietary energy which could potentially be redirected towards the meat or milk production (Patra and $\mathrm{Yu}, 2015$ ). This is especially the case in most areas of the developing countries, due to the low feed efficiency of the animals that lead to high cost in terms of $\mathrm{CH}_{4}$ produced per unit of animal product (Soltan et al., 2012).

Antibiotic ionophores are widely used in ruminant industry to improve energy and protein utilization and decrease $\mathrm{CH}_{4}$ emission (Russell and Strobel, 1989). However, there is a controversy about the use of these additives due to the risk of transferring residues into final animal products (meat and/or milk). These concerns have promoted the search for alternative natural additives such the secondary metabolites which occurring naturally in many plant species.

Moringa trees (Moringa oleifera) belonging to the Moringaceae family, have been used as an antibiotic in traditional medicine dates back thousands of years in many developing countries (Soliva et al., 2005 and Soltan et al., 2018). Among moringa parts, the leaf was the most part rich in various phytochemicals with high potency as antimicrobial, anti-cancerous, antianthelmintic, antispasmodic, anti-inflammatory properties (Sholapur and Patil 2013; Wang et al., 2016 and Soltan et al., 2017a). Thus there are many studies confirmed moringa leaves as dietary feed additives in livestock production, however, most of these studies were done for the whole leaf, while eliminating its extractions. Moreover, most of studies with the leaf extracts eliminated their antimethanogenic activity. Parts other than the leaves of moringa were suggested to 


\section{Soltan et al.}

be natural alternatives to monensin antibiotic to modulate $\mathrm{CH}_{4}$ emission towards more volatile fatty acids Recently, Soltan et al. (2018), found a similarity between moringa whole root bark and monensin in enhancing the growth performance of the growing lambs, while reduced $\mathrm{CH}_{4}$ emission relative to body weight gain. Thus, this provided a suggestion that if the chemical characterization of secondary metabolites of moringa leaf extract (MLE) and their mechanism of action can be clarified, they may introduce an alternative to replace the dietary antibiotic additives for ruminants. The objective of the current study is to evaluate in vitro the effects of two levels of MLE on ruminal fermentation, degradability and $\mathrm{CH}_{4}$ production compared to monensin.

\section{MATERIALS AND METHODS}

\section{Moringa origin, processing and analysis of the MLE:}

Fodder leaves of Moringa (Moringa oleifera) had been harvested in the first cutting. About $25 \mathrm{~kg}$ of fresh leaves were collected from a private farm located $45 \mathrm{~km}$ south of Alexandria $\left(30^{\circ} 50^{\prime} 56^{\prime \prime} \mathrm{N} 29^{\circ} 36^{\prime} 42^{\prime \prime} \mathrm{E}\right)$, Egypt. The leaves were collected from 50 trees, pooled, dried at $40^{\circ} \mathrm{C}$ for $72 \mathrm{~h}$ and milled through $1 \mathrm{~mm}$ screen.

Ten grams of moringa leaves were ground to a fine powder and mixed with $100 \mathrm{ml}$ ethanol $(700 \mathrm{ml} / \mathrm{l})$. The mixture was then ultrasonically for $30 \mathrm{~min}$. The ethanol extract solution was subsequently filtered and kept at $-5{ }^{\circ} \mathrm{C}$ overnight and was filtered again. The supernatant was transferred to the rotary evaporator (RE301/601/801, Yamato Scientific America Inc., USA) and treated at $42{ }^{\circ} \mathrm{C}$ for $30 \mathrm{~min}$ in order to remove the ethanol. The concentrated extract recovered in the volumetric flask was lyophilized for 3 days to get the experimental MLE that was used for the chemical analysis and the in vitro assay. The MLE was subjected to an in-depth compositional analysis using gas chromatography/mass spectrometry (Thermo Scientific TRACE- 1300 series GC) as described in details by Soltan et al. (2018).

\section{Basal diet, treatments and inocula preparation:}

The control total mixed ration was consisted of (g/kg DM): $500 \mathrm{~g}$ clover (Trifolium alexandrinum) hay, $200 \mathrm{~g}$ ground maize, $27.5 \mathrm{~g}$ soybean meal, $114.5 \mathrm{~g}$ wheat bran, $125 \mathrm{~g}$ cotton seed meal, $20 \mathrm{~g}$ limestone, $10 \mathrm{~g}$ sodium chloride and $3 \mathrm{~g}$ mineral premix. The ration was chemically analyzed based on DM $(\mathrm{g} / \mathrm{kg})$ according to $\mathrm{AOAC}(1995)$ as: $\mathrm{OM}=896.7$ and $\mathrm{CP}=141.6($ as $6.25 \times \mathrm{N})$. The neutral detergent fiber $(\mathrm{NDF})=505.9$, acid detergent fiber $(\mathrm{ADF})=252.6$, and lignin= 41 were measured sequentially using ANKOM Technology Corporation, Macedon, NY, USA, and expressed exclusive of residual ash as described by Goering and Van Soest (1970) and Van Soest (1973). The diet was formulated to meet NRC (2007) nutrient requirements recommended for growing sheep.

Four experimental treatments were evaluated as follow: control (the basal diet without supplementations, monensin [(the basal diet supplemented with the manufacturer's recommendation dose $(40 \mathrm{mg} / \mathrm{kg} \mathrm{DM})$ of ionophore sodium monensin (Rumensin ${ }^{\circledR}$, Elanco, Itapira, Brazil)], MLE was supplemented to the basal diet at two doses $50\left(\mathrm{MLE}_{\text {low }}\right)$ or $500\left(\mathrm{MLE}_{\text {high }}\right) \mathrm{mg} / \mathrm{kg} \mathrm{DM}$, respectively. The ionophore antibiotic monensin was selected because it is among the most common additives used to decrease $\mathrm{CH}_{4}$ emission and modulate ruminal fermentation characters (Soltan et al., 2018).

Four adult rumen-cannulated Barki sheep ( $58 \pm 2.5 \mathrm{~kg}$ body weight) were used as inoculum donors. The donner animals were fed ad libitum berseem clover hay and a concentrate feed mixture $(0.7 \mathrm{~kg} / 100 \mathrm{~kg}$ body weight, and containing $145 \mathrm{~g} / \mathrm{kg} \mathrm{DM}$ crude protein), and had free access to fresh water. Each treatment was incubated in four inocula, with each inoculum, four bottles per treatment were prepared, two for truly degraded organic matter (TDOM) determination and the other two for estimating the fermentation parameters. The same procedure was applied for the blanks (bottles containing the ruminal inoculum and the buffer solution without samples) to be able to correct the GP from the inoculum, and for an internal standard (bottles containing clover hay, ruminal inoculum and the buffer solution) to correct for sensitivity changes induced by the inoculum (Soltan et al., 2012).

\section{In vitro assay:}

A semi-automatic system of GP (Bueno et al., 2005) using a pressure transducer and a data logger (GN200, Sao Paulo, Brazil) with some modifications according to Soltan et al. (2018) was used. 
For $\mathrm{CH}_{4}$ determination, $2 \mathrm{ml}$ of the head space gas was sampled by a syringe (med Dawliaico, Assiut, Egypt) at each measuring event and stored in a $10 \mathrm{ml}$ vacutainer tubes (BD Vacutainer® Tubes, NJ, USA). Methane concentration was determined using a gas chromatograph (Model 7890, Agilent Technologies, Inc, Colorado 80537, USA), the separation conditions in details were described by Soltan et al. (2018). The test of linearity and calibration were accomplished using a standard gas curve in the range of probable concentrations of the samples using pure $\mathrm{CH}_{4}$ (Abu Qir Petroleum Co., Alexandria, Egypt; $939 \mathrm{ml} / \mathrm{l}$ purity). The amounts of $\mathrm{CH}_{4}$ produced were calculated according to Longo et al. (2006).

After termination of the incubation, all bottles were placed in ice to inhibit fermentation. Two bottles were assigned to the determination of the truly degraded dry matter and organic matter (TDDM and TDOM, respectively) following Blümmel and Becker (1997) method. The partitioning factor (PF: an indicator of ruminal microbial syntheses) was calculated as the ratio of TDOM (mg) and gas volume (ml) (Blümmel et al., 1997). The incubation liquid of the other two bottles was used for determining fermentation parameters and protozoal counts. The ammonia concentrations were evaluated calorimetrically by spectrophotometer (Alpha-1101 model; Labnics Equipment, California, USA) using commercial lab test (Konitzer and Voigt, 1963). The VFAs were determined following the method of Palmquist and Conrad (1971) using a gas chromatograph (Thermo fisher scientific, Inc., TRACE1300, Rodano, Milan, Italy) with some modifications described in details by Soltan et al. (2018). Protozoal abundance was counted by microscopy following the procedure of Dehority et al. (1983).

\section{Statistical analysis:}

Data were subjected to analysis of variance (ANOVA), using the PROC MIXED of SAS software package (2002). The four inocula were considered as the true statistical replicates. Each treatment was incubated in duplicate (analytical replicates) to achieve highly accurate estimate of a true replicate. The analytical replicates were averaged prior to statistical analysis with each inoculum being the statistical replicate, thus the statistical number of replications of treatments $(n=4)$ are the true statistical replications. The significant differences between individual means were considered significant at $\mathrm{P}<0.05$, whereas 0.05 $<\mathrm{P}<0.10$ were considered as a tendency by using Tukey test.

\section{RESULTS AND DISCUSSION}

\section{GC-MS analysis of MLE:}

Under the current GC-MS separation conditions, the most abundant compounds identified for MLE were branched chain amino acids (BCAA) since L-valine, L-alanine, L-leucine and L-isoleucine were 4.14, 3.90, 2.72 and $2.65 \%$, respectively. Other amino acids like L-threonine (1.38\%) was detected, components with benzene ring were detected in high concentration, glycosides were found (7.3\%), also 3-caffeoylquinic acid was $3.95 \%$ and butanedioic acid was $4.92 \%$ (Table 1). These combinations of moringa active components are found to be nutritionally and biologically active, e.g. its bioactive benzene fraction and glycosides are known to possess antibacterial, antifungal, and antioxidant properties (Alptüzün et al., 200 and Shah et al., 2016). Moreover, MLE can be considered as a good source of amino acids, because it contains considerable amounts of BCAA. These results are in accordance with Gopalakrishnan et al. (2016) who suggested that moringa leaves can be considered as a protein supplement due to the high content of essential amino acids (440 mg/kg DM). Although MLE have high content of various active components, little information is available about the effects of these components on ruminal fermentation or methanogenesis.

\section{Ruminal $\mathrm{CH}_{4}$, fermentation parameters and degradability:}

The results presented in Table (2) showed that no differences were observed for the gas production (GP), truly degraded dry matter (TDDM), truly degraded organic matter (TDOM) and partitioning factor (PF) among all the experimental treatments. The most efficient treatments to decrease $(\mathrm{P}<0.05) \mathrm{CH}_{4}$ were monensin and $\mathrm{MLE}_{\text {high }}$, where their proportional $\mathrm{CH}_{4}$ reduction was 18.1 and $15.5 \%$, respectively compared to the control. Currently, MLE high seemed to act against ruminal methanogenesis, thus likely adversely affecting Archaea as monensin did, and this finding suggest that MLE can be an alternative to the critical antibiotics feed additives in ruminant diets without adverse effects on GP or ruminal degradability. Previous studies also confirmed the antimethanogenic activity of moringa leaves studies, e.g. Dey et al. (2014) found an achievement of $\mathrm{CH}_{4}$ inhibition combined with enhancement of the total GP and organic matter 


\section{Soltan et al.}

degradability by wheat straw supplemented with moringa leaves in buffalo diets. Soltan et al. (2014) reported that extracts of moringa leaves and root barks could be used as effective natural alternatives to monensin in sheep diets, not only to decrease $\mathrm{CH}_{4}$ emission, but also to increase the ruminal nutrient degradability. Similarly, Soliva et al. (2005) found that $\mathrm{CH}_{4}$ production was inhibited significantly by $17 \%$ with moringa leaves based diet as compared to the diets containing rapeseed meal or soybean meal, without adverse effects on the ruminal fermentation or nutrient degradability, the authors suggested that such effects might relate to existence of bioactive components in moringa leaves, however no specific bioactive components were assigned to confirm such suggestion.

Table (1): Individuality of constituents in the moringa leaf extract (MLE) determined by gas chromatography/mass spectrometry.

\begin{tabular}{|c|c|c|c|}
\hline Peak & Name & $\%$ Area & RT \\
\hline 1 & Benzene, 1,1'-[4-(3-phenylpropyl)-1, 7-heptanediyl]bis- (CAS) & 8.17 & 2.03 \\
\hline 2 & L-alanine, $\mathrm{N}$-(trimethylsilyl)-, trimethylsilyl ester & 3.90 & 7.295 \\
\hline 3 & L-valine, $\mathrm{N}$-(trimethylsilyl)-, trimethylsilyl ester & 4.14 & 10.090 \\
\hline 4 & L-leucine, $\mathrm{N}$-(trimethylsilyl)-, trimethylsilyl ester & 2.72 & 11.519 \\
\hline 5 & L-isoleucine, $\mathrm{N}$-(trimethylsilyl)-, trimethylsilyl ester & 2.65 & 12.085 \\
\hline 6 & Hexasiloxane, $1,1,3,3,5,5,7,7,9,9,11,11$-dodecamethyl- & 2.88 & 12.147 \\
\hline 7 & Propanoic acid, 2,3-bis[(trimethylsilyl)oxy]-, trimethylsilyl ester & 0.77 & 13.097 \\
\hline 8 & Carotene, 3,4-didehydro-1,1',2,2'-tetr ahydro-1'-hydroxy-1-methoxy- & 3.03 & 13.842 \\
\hline 9 & L-threonine, N,O-bis(trimethylsilyl)-, trimethylsilyl ester & 1.38 & 14.533 \\
\hline 10 & Butanedioic acid, [(trimethylsilyl)oxy]-, bis(trimethylsilyl) ester & 4.92 & 17.032 \\
\hline 11 & $\mathrm{Nd}$ & 2.40 & 17.763 \\
\hline 12 & Trimethylsilyl 2,3,4-tris[(trimethylsilyl)oxy]butanoate & 2.54 & 18.896 \\
\hline 13 & Glucofuranoside, methyl 2,3,5,6-tetrakis-o-(trimethylsilyl)-, .alpha.-D- & 1.61 & 24.118 \\
\hline 14 & D-fructose, 1,3,4,5,6-pentakis-o-(trimethylsilyl)- & 6.02 & 24.335 \\
\hline 15 & D-fructose, 1,3,4,5,6-pentakis-o-(trimethylsilyl)- & 4.73 & 24.494 \\
\hline 16 & Mannofuranoside, methyl 2,3,5,6-tetrakis-o-(trimethylsilyl)-, .alpha.-D- & 3.57 & 25.105 \\
\hline 17 & no-2,4-dimethyl-1H-pyrrol- 3-yl)-2-methyl-4H-pyran-3 -carboxylic acid ethyl ester & 1.95 & 25.464 \\
\hline 18 & Beta.-D-galactofuranose, 1,2,3,5,6-pentakis-o-(trimethylsilyl)- & 6.90 & 27.940 \\
\hline 19 & Beta.-D-galactofuranose, 1,2,3,5,6-pentakis-o-(trimethylsilyl)- & 2.69 & 28.229 \\
\hline 20 & 4-(Pentadeuterio)phenylazulene & 1.85 & 29.849 \\
\hline 21 & Colchiceine & 1.86 & 34.958 \\
\hline 22 & Benzene, 2-(1-decyl-1-undecenyl)-1, 4-dimethyl- (CAS) & 9.15 & 37.203 \\
\hline 23 & 2,3-Bis(3'-Methoxy-2'-nitro phenylimino)-2H-indole & 2.40 & 37.547 \\
\hline 24 & $\begin{array}{l}\text { 1,3,4,6-tetrakis-o-(trimethylsilyl)hex-2-ulofuranosyl 2,3,4,6-tetrakis-o- } \\
\text { (trimethylsilyl)hexopyranoside }\end{array}$ & 7.30 & 38.176 \\
\hline 25 & $\begin{array}{l}\text { Alpha.-D-glucopyranoside, 1,3,4,6-tetrakis-o-(trimethylsilyl)-.beta.-d fructofuranosyl } \\
\text { 2,3,4,6-tetrakis-o-(trimethylsilyl)- }\end{array}$ & 5.96 & 38.973 \\
\hline 26 & 2(3,4bis[(trimethylsilyl)oxy]phenyl)-3,5,7 tris[(trimethylsilyl)oxy]-4h-chromen-4-one & 0.56 & 45.744 \\
\hline 27 & Hexatrimethylsilyl-trans-3-o-caffeoyl-d-quinic acid & 3.95 & 46.101 \\
\hline
\end{tabular}

Table (2): Effect of monensin, and moringa leaf extract (MLE) on ruminal gas production (GP), degradability and partitioning factor (PF).

\begin{tabular}{|c|c|c|c|c|c|c|}
\hline \multirow[t]{2}{*}{ Item } & \multicolumn{4}{|c|}{ Treatments } & \multirow[t]{2}{*}{ SEM } & \multirow[t]{2}{*}{$P$ value } \\
\hline & Control & Monensin & MLE $_{\text {Low }}$ & MLE $_{\text {High }}$ & & \\
\hline GP (mL/g DM) & 150.4 & 143.3 & 160.4 & 159.6 & 22.71 & 0.4241 \\
\hline $\mathrm{CH}_{4}(\mathrm{~mL} / \mathrm{g} \mathrm{TDOM})$ & $34.80^{\mathrm{a}}$ & $28.49^{\mathrm{b}}$ & $32.95^{\mathrm{A}}$ & $29.39^{\mathrm{b}}$ & 7.861 & 0.0199 \\
\hline TDDM $(\mathrm{g} / \mathrm{kg})$ & 620.5 & 611.3 & 603.4 & 610.8 & 41.189 & 0.1214 \\
\hline TDOM (g/kg) & 597.06 & 595.8 & 562.7 & 610.9 & 38.344 & 0.1993 \\
\hline Partitioning factor (PF) & 2.2010 & 1.9396 & 1.939 & 2.431 & 0.4148 & 0.216 \\
\hline
\end{tabular}

GP: net gas production; $\mathrm{CH}_{4}$ : methane; TDDM: truly degraded dry matter; TDOM: truly degraded organic matter; SEM: Standard error of the mean.

${ }^{a, b}$ : Means within a row without a common superscript letter differ significantly $(P<0.05)$.

Most common methanogen inhibitors negatively affect the ruminal fermentation or/ and organic matter degradability at doses that achieve desirable methane reduction (Patra and Yu, 2015). Currently, although 
the reasons for methane inhibition caused by MLE remain to be explored, it seems that MLE affected the methanogenesis directly, since the ruminal degradability and the protozoal counts remained unchanged. Thus combinations between antibacterial and antioxidant bioactive components in MLE might play a key role in that concern (Alptüzün et al., 2009, Soltan et al., 2018).

Table (3) presented the in vitro effects of MLE and monensin on ruminal $\mathrm{pH}$, ammonia concentrations, protozoal count and VFAs. No significant differences were observed among the experimental treatments in the ruminal $\mathrm{pH}$ or ammonia concentrations, while a decline $(\mathrm{P}<0.05)$ in protozoal count was observed by monensin, but such effect did not appear at other treatments. Methanogen inhibitors can reduce $\mathrm{CH}_{4}$ production directly or indirectly ways through the inhibition of numbers or activity of methanogens and antiprotozoal properties, respectively (Cieslak et al., 2013). Monensin was found to alternate the ruminal hydrogen-sink products directly towards less $\mathrm{CH}_{4}$ production through a shift in hydrogen usage from methanogenesis and /or formate to propionate or succinate production by the inhibition of gram-positive bacteria (Russell and Strobel, 1989 and Schären et al., 2017). Moreover, the antiprotozoal effect of monensin might partially help to explain the indirect reduction in $\mathrm{CH}_{4}$ emission. Thus currently, the tendency $(\mathrm{P}=0.08)$ in enhancement of propionate production and decreasing $(\mathrm{P}<0.05)$ the acetate to propionate ratio caused by monensin without affecting the total VFAs production may support the above suggestion. On other hand, the reduction of $\mathrm{CH}_{4}$ caused by $\mathrm{MLE}_{\text {high }}$ was combined by an enhancement $(\mathrm{P}<$ 0.05 ) in the total VFAs production. This may be due to the presence of components with antioxidant activity (e.g. glycosides and 3-caffeoylquinic acid) in MLE. Recently, many studies confirmed that the presence of these components would lessen oxidative stress and promote better conditions for ruminal fermentation (Soltan et al., 2017b, 2018). Such enhancement in total VFAs production found by MLE high might partly confirm this hypothesis, since VFAs are the principal outcome of the ruminal fermentation (Calsamiglia et al., 2007). The reasons for the increases in VFAs by MLE are not clear, however the high content of essential amino acids (BCAA) found in MLE may parley explain such effect. Nouman et al. (2014) reported that the dietary supplementation of valine, leucine and isoleucine enhanced the production of total VFAs. Thus, the current results suggested that the fermentation pathways expended $\mathrm{H}_{2}$ to produce VFAs than $\mathrm{CH}_{4}$ and these increases of VFAs could be attributed to acetate enhancement, hence acetate are the major part of the total VFAs produced by ruminal microbes (Calsamiglia et al., 2007 and Soltan et al., 2017b). Reduction of $\mathrm{CH}_{4}$ combined with enhancement $(\mathrm{P}<0.05)$ of acetate caused by MLE high may suggest that MLE stimulates acetogenesis as an alternative to the ruminal methanogenesis. Ruminal methanogenesis pathway is the primary $\mathrm{H}_{2}$ sink, while acetogens have a poorer affinity to $\mathrm{H}_{2}$ than methanogens (Tan et al., 2011). Thus the current results may refer to a competition happened between methanogenesis and acetogenesis for $\mathrm{H}_{2}$ binding. Recently, many studies have also suggested that acetogensis can serve as an alternative hydrogenotrophic pathway in the rumen (El-Zaiat et al., 2014 and Soltan et al., 2017b).

Table (3): Effect of monensin and moringa leaf extract (MLE) on some ruminal parameters.

\begin{tabular}{lllllll}
\hline \multirow{2}{*}{ Item } & \multicolumn{3}{c}{ Treatments } & \multirow{2}{*}{ SEM } & $P$ value \\
\cline { 2 - 5 } & Control & Monensin & MLE $_{\text {Low }}$ & MLE $_{\text {High }}$ & & \\
\hline $\mathrm{pH}$ & 5.98 & 5.99 & 5.93 & 5.94 & 0.327 & 0.991 \\
$\mathrm{NH}_{3}-\mathrm{N}(\mathrm{mg} / 100 \mathrm{~mL})$ & 22.1 & 22.8 & 24.5 & 24.7 & 4.557 & 0.110 \\
$\mathrm{VFAs}$ & & & & & & \\
Total $(\mathrm{mM})$ & $46.9^{\mathrm{b}}$ & $46.7^{\mathrm{b}}$ & $48.1^{\mathrm{b}}$ & $57.9^{\mathrm{a}}$ & 1.267 & 0.001 \\
Acetate, \% & $64.2^{\mathrm{ab}}$ & $61.4^{\mathrm{b}}$ & $63.7^{\mathrm{ab}}$ & $64.8^{\mathrm{a}}$ & 0.687 & 0.028 \\
Propionate, \% & 16.2 & 18.5 & 16.9 & 16.5 & 0.358 & 0.082 \\
Butyrate, \% & 14.1 & 15.39 & 14.0 & 15.3 & 0.467 & 0.164 \\
Isobutyrate, \% & 1.07 & 1.18 & 1.09 & 1.18 & 0.120 & 0.880 \\
Valerate, \% & 1.68 & 1.79 & 1.62 & 1.67 & 0.100 & 0.663 \\
Isovalerate, $\%$ & 1.56 & 1.80 & 1.57 & 1.78 & 0.246 & 0.889 \\
C2:C3 & 3.74 & 3.38 & 3.82 & 3.99 & 0.091 & 0.084 \\
Protozoa $\times 10^{5}$ & $4.943^{\mathrm{a}}$ & $3.937^{\mathrm{b}}$ & $5.381^{\mathrm{a}}$ & $5.212^{\mathrm{a}}$ & 0.7502 & 0.009 \\
\hline SEM & & & & & & \\
\hline
\end{tabular}

SEM: Standard error of the mean.

SEM: Standard error of the mean.
a,beans within a row without a common superscript letter differ significantly $(P<0.05)$. 


\section{Soltan et al.}

The PF is an indicator of the efficiency of microbial protein synthesis (Blümmel et al., 1997), none of the experimental additives affected the PF (Table 3). The lack of change in PF values is consistent with the rather constant of ammonia concentrations suggested that the nitrogen use by microbes for their protein synthesis remained unchanged, and the VFAs probably enhanced by ruminal microbes which are not involved in the amino acids degradation.

No differences were detected between MLE low and the control treatments either in the ruminal degradability or the fermentation parameters. These findings suggest that MLE $_{\text {low }}$ was an inadequate dose to affect the ruminal microbial ecosystem, thus it is important to choose the effective dose of MLE to be applicable in the ruminant's diets. Generally, the effects of MLE either through reducing $\mathrm{CH}_{4}$ or enhancing the production of VFAs may be nutritionally advantageous to ruminants, due to the increases in the energy supply to animals consequently enhance the whole animal productivity.

\section{CONCLUSION}

The current study suggested that MLE can be used as an effective additive for ruminants' diets in the field of smart agriculture. Both MLE and monensin exhibited a similar antimethanogenic activity without adverse effects on ruminal degradability however; they were different in their mode of action. Monensin reduced $\mathrm{CH}_{4}$ through enhancing propionate production, while MLE enhanced the acetate production. These results also suggested that the consideration of MLE as a dietary supplementation to modify the ruminal fermentation was dose dependent. Further research should focus on the in vivo long-term effects of the dietary MLE to be applicable as one of the climate smart agriculture practices in the developing countries.

\section{REFERENCES}

Alptüzün, V., S. Parlar, H. Hüseyin Taşl and E. Erciyas (2009). Synthesis and Antimicrobial Activity of Some Pyridinium Salts. Molecules, 14: 5203-5215

AOAC (1995). Association of Analytical Chemists, Official Methods of Analysis, $18^{\text {th }}$ ed., Gaithersburg, MD, USA.

Blümmel, M. and K. Becker (1997). The degradability characteristics of fifty-four roughages and roughage neutral-detergent fibre as described by in vitro gas production and their relationship to voluntary feed intake. British Journal of Nutrition, 77: 757-786.

Blümmel, M., H. Steingass and K. Becker (1997). The relationship between in vitro gas production, in vitro microbial biomass yield and $15 \mathrm{~N}$ incorporations for the prediction of voluntary feed intake of roughages. British Journal of Nutrition, 77: 911-921.

Bueno, I.C.S., S.L.S. Filho, S.P. Gobbo, H. Louvandini, D.M.S.S. Vitti and A.L. Abdalla (2005). Influence of inoculum source in a gas production method. Animal Feed Science and Technology, 123: 95-105.

Calsamiglia, S., M. Busquet, P.W. Cardozo, L. Castillejos and A. Ferret (2007). Essential oils as modifiers of rumen microbial fermentation. Journal of Dairy Science, 90: 2580-2595.

Cieslak, A., M. Szumacher-Strabel, A. Stochmal and W. Oleszek (2013). Plant components with specific activities against rumen methanogens. Animal 7: 253-265.

Dehority, B.A., W.S. Damrona and J.B. McLaren (1983). Occurrence of the rumen ciliate Oligoiso trichabubali in domestic cattle (Bostaurus). Applied and Environmental Microbiology, 45: 1394-1397.

Dey, A., S.S. Paul, P. Pandey and R. Rathore (2014). Potential of Moringa oleifera leaves in modulating in vitro methanogenesis and fermentation of wheat straw in buffalo. Indian Journal of Animal Science, 84: 533-538.

El-Zaiat, H.M., R.C. Araujo, Y.A. Soltan, A.S. Morsy, H. Louvandini, A.V. Pires, H.O. Patino, P.S. Correa and A.L. Abdalla (2014). Encapsulated nitrate and cashew nut shell liquid on blood and rumen 
constituents methane emission, and growth performance of lambs. Journal of Animal Science, 92: 22142224.

Goering, H.K., and P.J. Van Soest (1970). Forage fibre analysis (apparatus, reagents, procedures and some applications). Agric. Handbook No. 379. US Agricultural Research Service, Washington, DC.

Gopalakrishnan, L., K. Doriyaaa and D.S. Kumar (2016). Moringa oleifera: A review on nutritive importance and its medicinal application. Food Science and Human Wellness, 5: 49-56.

Konitzer, K. and S. Voigt (1963). Direct determination of ammonium in blood and tissue extracts by means of the phenol by chlorite reaction. Clinica Chimica Acta, 8: 5-11.

Longo, C., I.C.S. Bueno, E.F. Nozella, P.B. Goddoy, S.L.S. Cabral Filho and A.L. Abdalla (2006). The influence of head-space and inoculum dilution on in vitro ruminal methane measurements. In: Soliva, C.R., Takahashi, J., Kreuzer, M. (Eds.), Greenhouse Gases and Animal Agriculture: An Update Int. Congr. Series No. 1293. Elsevier, The Netherlands, pp. 62-65.

Nouman, W., S.M.A. Basra, M.T. Siddiqui, A. Yasmeen, T. Gull and M.A.C. Alcayde (2014). Potential of Moringa oleifera L. as livestock fodder crop: a review. Turkish Journal of Agriculture and Forestry, 38: 1-14.

NRC (2007). National Research Council. Nutrient Requirements of Small Ruminants: Sheep, Goats, Cervids, and New World Camelid. The National Academy of Sciences, Washington, DC, USA.

Palmquist, D. and H. Conrad (1971). Origin of plasma fatty acid in lactating dairy cows fed high fat diets. Journal of Dairy Science, 54: 1025-1031.

Patra, A.K. and K. Yu (2015). Effects of adaptation of in vitro rumen culture to garlic oil, nitrate, and saponin and their combinations on methanogenesis, fermentation, and abundances and diversity of microbial populations. Frontiers in Microbiology, 119: 127-138.

Russell, J.B. and H.J. Strobel (1989). Effect of ionophores on ruminal fermentation. Mini review. Applied and Environmental Microbiology, 55: 1-6.

SAS (2002). Statistical Analysis System. SAS PC Windows Version 9.2.0. SAS Institute Inc., Cary, NC, USA.

Schären, M., C. Drong, K. Kiri, S. Riede, M. Gardener, U. Meyer, J. Hummel, T. Urich, G. Breves and S. Dänicke (2017). Differential effects of monensin and a blend of essential oils on rumen microbiota composition of transition dairy cows. Journal of Dairy Science, 100: 2765-2783.

Shah, S.K., D.N. Jhade and R. Chouksey (2016). Moringa oleifera Lam. a study of ethnobotany, nutrients and pharmacological profile. Research Journal of Pharmaceutical, Biological and Chemical Sciences, 7: 2158-2165.

Sholapur, H.P.N. and B.M. Patil (2013). Pharmacognostic and phytochemical investigations on the bark of Moringa oleifera Lam. Indian Journal of Natural Products and Resources, 1: 96-101.

Soliva, C.R., M. Kreuzer, N. Foid, G. Foid, A. Machmüller and H.D. Hess (2005). Feeding value of whole and extracted Moringa oleifera leaves for ruminants and their effects on ruminal fermentation in vitro. Animal Feed Science and Technology, 118: 47-62.

Soltan, Y.A., R.C. Lucas, A.S. Morsy, H. Louvandini and A.L. Abdalla (2014). The potential of Moringa oleifera leaves, root bark and propolis extracts for manipulating rumen fermentation and methanogenesis in vitro, International Symposium on Food Safety and Quality: Applications of Nuclear and Related Techniques IAEA Headquarters, Vienna, Austria, 10-13 November 2014.

Soltan Y.A., A.S. Morsy, N.M. Hashem and S.M. Sallam (2017a). Utilization of Moringa oleifera in ruminant nutrition (Review article). Sustainable Development of Livestock`s Production Systems" (SDLPS)" from 7-9 November, 2017. Department of Animal Production, Faculty of Agriculture, Alexandra University, Egypt.

Soltan, Y.A., A.S. Morsy, R.C. Lucas and A.L. Abdalla (2017b). Potential of mimosine of Leucaena leucocephala for modulating ruminal nutrient degradability and methanogenesis. Animal Feed Science and Technology, 223: 30-41. 


\title{
Soltan et al.
}

Soltan, Y.A., A.S. Morsy, S.M.A. Sallam, H. Louvandini and A.L. Abdalla (2012). Comparative in vitro evaluation of forage legumes (prosopis, acacia, atriplex, and leucaena) on ruminal fermentation and methanogenesis. Journal of Animal Feed and Sciences, 21: 759-772.

Soltan, Y.A., N.M. Hashem, A.S. Morsy, K. M. El-Azrak, A. Nour El-Din and S.M. Sallam (2018). Comparative effects of Moringa oleifera root bark and monensin supplementations on ruminal fermentation, nutrient digestibility and growth performance of growing lambs. Animal Feed Science and Technology, 235: 189-201.

Tan, H.Y., C.C. Sieo, N. Abdullah, J.B. Liang, X.D. Huang and Y.W. Ho (2011). Effects of condensed tannins from Leucaena on methane production, rumenfermentation and populations of methanogens and protozoa in vitro. Animal Feed Science and Technology, 169: 185-193.

Van Soest, P.J. (1973). Collaborative study of acid detergent fibre and lignin. Journal of the Association of Official Analytical Chemists, 56: 781-784.

Wang, L., X. Chen and A. Wu (2016). Mini review on antimicrobial activity and bioactive compounds of Moringa oleifera. Journal of Medicinal Chemistry, 6: 578-582.

\section{تأثير إضافة مستخلص أوراق المورنجا علي هلم العناصر الغذائية بالكرش وخفض تكوين غاز الميثان معمليا}

\author{
يسرا أحمد سلطان ، ، عمرو صلاح مرسي² ، نسرين لمحم هاشم و صبحي محم عبد الله سلام \\ 1 قسم الاتتاج الحيواني و السمكي_كلية الزراعة- جامعة الاسكنلدية- الاسكندريهـ مصر. \\ 2 مدينة الابحاث العلمية و التطبيقات التكنولوجيةـ معطل بحوث الاراضي القاطلة الاسكندرية ـ مصر.
}

\begin{abstract}
تعد المستخلصات النباتية من أحد الوسائل الفعالة لاحلال المضادات الحيوية والتي تستخدم كاضافات علفية لعلائق

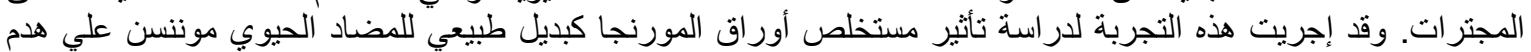

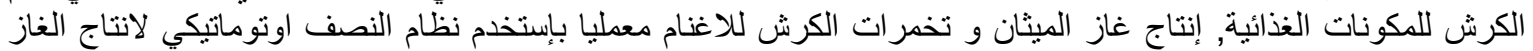

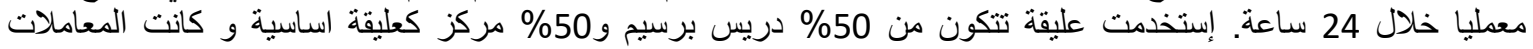

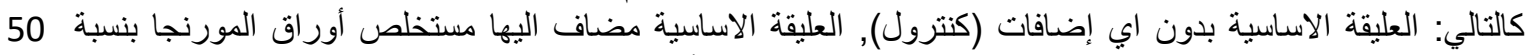

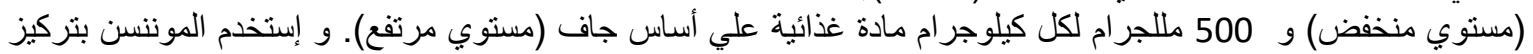

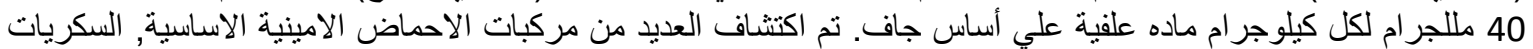

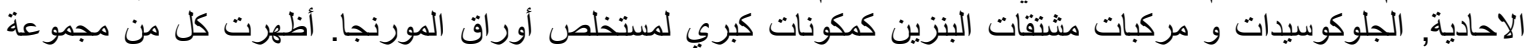

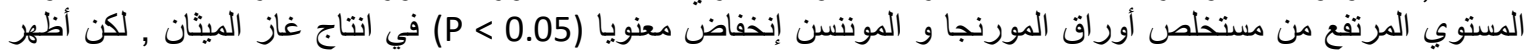

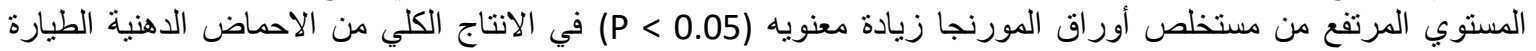

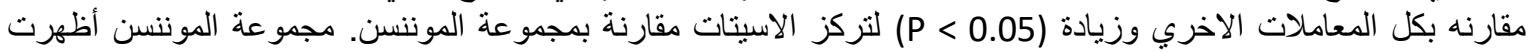

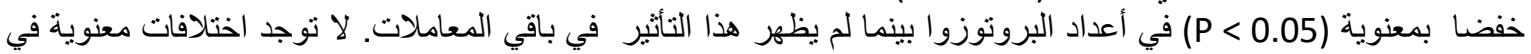

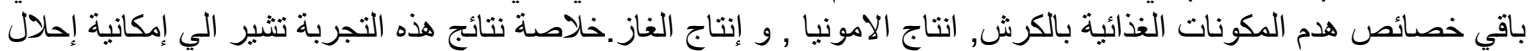
مستخلص أوراق المورنجا محل الموننسن في علائق الاغنام لخفض إنتاج المناج الميثان.
\end{abstract}

